\title{
What Makes Muslim Travellers Satisfied? An Empirical Study of Indonesian Muslim Travelers to West Europe on a Group Tour
}

\author{
Farshal Hambali \\ Sekolah Tinggi Pariwisata Trisakti \\ Jakarta, Indonesia \\ farshal267@gmail.com
}

\begin{abstract}
Indonesia is the world largest country populated by Muslim, although the basis of the nation is secular and not based on Islam or Syariah. The total Muslim population in Indonesia is 207 Million (Indonesia-Investments.com). This is a substantial market segment with special needs and requirement, travel is not an exception. For Muslim, all activities in life including traveling is about worship to the Almighty God. There are specific travel needs for the Molem travellers that any travel supplier and organizers must fulfil in order to gain satisfaction. This qualitative research is to understand critical success factors for travel agents, tour operators, airlines, hotels, tourism attractions, souvenir shops in order to win satisfaction from Muslim travellers. In this research we choose the West Europe Tour Product which consist destinations in France, Germany, Netherlands, Switzerland and Belgium. West Europe is one of the most popular tour products to many Indonesians. The raising middle class in Indonesia which are dominated by Muslim, with specific travel needs, are important to any travel suppliers, especially when they travel abroad to a non- Muslim destinations. The numbers tend to grow, exponentially year on year. Travel suppliers and destinations must be prepare to meet these specific needs. Muslim travellers and Halal industry is a new phenomenon in travel and tourism. This is a research on progress as data and statistical information are currently limited. Research is heavily dependent on expert opinion and industry practicionaire which is presently limited
\end{abstract} factor

Keywords-Muslim travellers, Customer satisfaction, Success

\section{INTRODUCTION}

Islam is one of the world ${ }^{\text {ee }} \mathrm{s}$ largest religions. It has nearly 1.8 Billion followers around the Globe. Indonesia is the largest country populated by Muslim, although the basis is nationalist or secular state. The Indonesia Investment Board stated there are 207,000,000 Million Muslims in Indonesia spreading in the 33 provinces. This is approximately $12 \%$ of the total world Muslim population.

We have seen global phenomena of Halal Industry, Islamic fashion, Islamic finance growing exponentially for the past couple of years. Islamic way of life is now trending and becoming lifestyle in particular in countries where Muslims are majority or dominant. From the business and economic point of view, this is a substantial market to tap into. Any businesses are now focusing on how to win Muslim market segment, as they all have special needs and requirements. On the food industry, Halal is the most important requirements for any Muslims. Therefore any businesses in Food need to obtain the so called Halal certificates from the appropriate authorities in order to win business from Muslim market segment.

The Muslim travel market continues to be one of the fastest growing segments in the global travel industry. In 2015, it was estimated that there were 117 million Muslim international travelers. This is projected to grow to 168 million by 2020 , where the travel expenditure by Muslim travelers is expected to exceed USD 200 billion (MasterCard, 2016)

The key drivers of Muslim travel growth are as follows (MasterCard CresentRating, 2016):
a. Population growth
b. Growing middle class
c. Younger population
d. Increasing access to travel information
e. Increasing availability of Muslim- friendly travel services and facilities

Growing Muslim population, The Muslim population is growing rapidly and is expected to make up 26 percent of the world ${ }^{\text {ee }} \mathrm{s}$ population by 2030 . This translates to one out of three people born between 1990 and 2030 being Muslim.

Growing middle class / Disposable income: The middle class in countries with large Muslim populations are increasing. These include Gulf countries, Indonesia, Malaysia, Turkey, Nigeria and Bangladesh. The 2nd and 3rd generation of Muslims in Western Europe and North America are also becoming highly educated and entering the professional work force. All of this is increasing the disposable income of a large Muslim consumer base.

Younger population: According to Pew research, "Muslims are also the youngest (median age of 23 years old in 2010) of all major religious groups, seven years younger than the median age of non- Muslims." They are better informed and are actively influencing the travel planning of their family holidays. 
Increasing access to travel information: The proliferation of Internet access coupled with high penetration of smartphones have made travel planning easier in general. Muslim majority countries such as Saudi Arabia and the UAE are among the top countries when it comes to smartphone penetration. A younger more technology-savvy population also means more Muslims are active on social media and use it to get information.

Increasing availability of Muslim-friendly travel services and facilities: The last few years have seen many businesses and destinations beginning to adapt their products and services to cater to Muslim travelers. This has meant that there is an increasing availability of Muslim-friendly services. Halal food is available in many major cities now.

The research on this paper is to look at Indonesian Muslim Travelers to West Europe which is one of the most popular outbound tour products from Indonesia to Europe. Destinations are including cities in France, Germany, Netherlands, Belgium and Switzerland. The research problem on this paper is to look at following matters:

a. Factors that makes Muslim travelers satisfied when they travel to West Europe

b. The efforts of Travel Agents to satisfy the Muslim travelers need

And therefore the research objective is to understand what factors and criteria that make Muslim travelers satisfied when they purchase West Europe tour product. The paper will also describe the effort of Travel Agents to pursue highest level of Muslim traveller"s satisfaction with their package and product offerings. The research is expected to give benefit to Muslim Specialist Travel Agents in their quest to Customer Satisfaction and ongoing improvement on their service quality. CresentRating, the worlde's leading authority in Halal friendly travel has identified following Key Faith Based Needs for Muslim Travelers (GMTI, 2016).

Halal Food: Halal food is by far the most important service that a Muslim traveler looks out for when traveling. Acceptability of the different levels of Halal food assurance varies among Muslims. The acceptability also varies depending on the region the Muslim travelers are coming from. Having food outlets with proper Halal assurance that is easily identifiable is the preferred option sought by Muslim visitors from Southeast Asia and Western Europe.

Prayer Facilities: Prayer is one of the central elements of Islamic practice and worship and it is the second of the five pillars of Islam. According to the Pew Research Centre report, 63 percent of Muslims perform the five daily prayers. While traveling, some of them will combine some prayers and perform them three times a day In order to cater to this need, the services and facilities that are frequented by Muslim travelers need to be equipped with prayer rooms. Another important consideration is the cleansing ritual referred to as Wudhu. Wudhu is performed before a Muslim performs their prayers. This requires the prayer rooms to have "foot washing" facilities.

Water-usage friendly Washrooms, for Muslims, water plays a key role in purity and cleanliness, both of which are core aspects of the faith. Physical cleanliness is stressed as an essential component of being a Muslim. As such, special attention is given to hygiene in the washroom. This entails the use of water in the toilets, and it is discomforting for Muslim travelers where the setup for water use is not available. Providing such facilities has become less cumbersome now with the widespread availability of hand showers, bidets or even Japanese-style toilets. Common in Muslim countries as well as South and Southeast Asian countries, the hand shower is a plumbing fixture placed in a holder against a wall by the toilet.

Ramadan Services : Although Muslims are less likely to travel during the month of Ramadan, there are still many looking to spend this time away from home, especially if this period coincides with school holidays. In addition, an increasing number of Muslims take holiday breaks during the two Muslim festivals. Destinations looking to attract Muslim travelers during this period need to be able to accommodate their special needs during the month of fasting. One such example is the catering of pre- dawn Halal meals by hotels.

No Non-Halal Activities: Muslims consider some activities to be „Haram or non-Halal. When it comes to traveling, these are generally centered on requiring a familyfriendly environment. As such, some Muslims would prefer to avoid facilities that servealcohol, have discotheques or is adjacent to a gambling resort.

Recreational Facilities and Services with Privacy: A subsegment of Muslim travelers are also looking for recreational facilities that provide privacy for males and females. These include the following a/ Swimming pools and gyms that provide privacy for male and female use, and b/ Beaches, which provide areas for males and females to enjoy in privacy.

Segmentation of Muslim Travelers Based on Faith-Based Needs: Muslim travelers are not homogeneous in their adherence to the faith-based needs discussed above. In order to cater to these needs from a services perspective, service providers can look at grouping these needs into "Need to have, good to have and Nice to have. In this case the need to have is Halal food service and Pray facilities. The good to have water- usage friendly washrooms and Ramadan facilities, and finally the nice to have is the No-non halal activities and recreational facilities. The Muslim Traveller Solutions (Abadi,2016) outline three most important aspects to satisfied Muslim Travellers needs and they are:

a. Halal food. This is a compulsory item, a must to have for Muslim travellers. Travel agent must ensure that all meals provided are halal, where possible meals provided are halal certified. When certification is not possible, travel agent must ensure that advance inspection to service provider kitchen for example, are made with proper checklist.

b. Pray at the Mosque to be includes in the itinerary and tour program. Travel agent must ensure that pray at the mosque is in the daily itinerary and where possible including the Friday Prayer when fall into Friday. 
c. Pray services. Travel agent must ensure that information is passed in regards to pray times (5 times a day) in each location. Tour itinerary must include pray times, details of pray facilities. Where possible the morning pray to be done together (Jamaah) in the hotel therefore requires dedicated space from the hotel.

In addition, Subekti in Abadi, 2016 also indicate three important elements in the Muslim Travels, halal food is compulsory, availability of pray times in each location and pray services. The nice to have is the preaching sessions on daily basis. This is important as at each point of interest there are stories to share, and most of all to always be grateful of God creation.

\section{A. Religious Motivations}

Motivation plays a significant satisfaction refers to the pleasure of the tourist after role in travelling. There is a close relationship between tourism and religious motivation. Henderson found that some tourists are religiously motivated to visit religious destinations. Priyadi in Muslim Traveller Solution explains that Muslim Travels to see the Great Creation of Allah (2006) Religious destinations refer to any event, religious festival, or memorable place. Religious tourism gives tourist mental and spiritual benefits. In Islamic tourism, Muslims do not just visit places; rather they seek the mercy of Allah S.W.T For instance, during the Hajj and Umrah pilgrimages, Muslims are satisfying one pillar of the five pillars of Islam.

\section{B. Service Quality}

Service quality is considered as a critical dimension of competitiveness (Lewis, 1989). Providing excellent service quality and high customer satisfaction is the important issue and challenge facing the contemporary service industry (Hung et al., 2003). Service quality is an important subject in both the public and private sectors, in business and service industries (Zahari et al., 2008). Service quality is a concept that has aroused considerable interest and debate in the research literature because of the difficulties in both defining it and measuring it with no overall consensus emerging on either (Wisniewski, 2001). One that is commonly used defines service quality as the extent to which a service meets customers ${ }^{\text {ee }}$ needs or expectations (Lewis and Mitchell, 1990; Dotchin and Oakland, 1994a; Asubonteng et al, 1996; Wisniewski and Donnelly, 1996). Service quality can thus be defined as the difference between customer expectations of service and perceived service.

If expectations are greater than performance, then perceived quality is less than satisfactory and hence customer dissatisfaction occurs (Parasuraman et al.,1985; Lewis and Mitchell, 1990). Always there exists an important question: why should service quality be measured? Measurement allows for comparison before and after changes, for the location of quality related problems and for the establishment of clear standards for service delivery. Edvardsen et al. (1994) state that, in their experience, the starting point in developing quality in services is analysis and measurement. The
SERVQUAL approach, which is studied in this paper, is the most Common method for measuring service quality.

\section{Servqual}

Clearly, from a Best Value perspective the measurement of service quality in the service sector should take into account. customer expectations of service as well as perceptions of service. However, as Robinson (1999) concludes: "It is apparent that there is little consensus of opinion and much disagreement about how to measure service quality". One service quality measurement model that has been extensively applied is the SERVQUAL model developed by Parasuraman et al. (1985, 1986, 1988, 1991, 1993, 1994; Zeithaml et al., 1990). SERVQUAL as the most often used approach for measuring service quality has been to compare customers' expectations before a service encounter and their perceptions of the actual service delivered (Gronroos, 1982; Lewis and Booms, 1983; Parasuraman et al., 1985). The SERVQUAL instrument has been the predominant method used to measure consumers" perceptions of service quality. It has five generic dimensions or factors and is stated as follows (van Iwaarden et al., 2003):

a. Tangibles. Physical facilities, equipment and appearance of personnel.

b. Reliability. Ability to perform the promised service dependably and accurately.

c. Responsiveness. Willingness to help customers and provide prompt service.

d. Assurance (including competence, courtesy, credibility and security). Knowledge and courtesy of employees and their ability to inspire trust and confidence.

e. Empathy (including access, communication, understanding the customer). Caring and individualized attention that the firm provides to its customers.

In this paper, the application of SERVQUAL approach is more specified with an example for travel agent business.

\section{METHOD}

This is a qualitative research which is mainly based on primary data collection. The purpose of this research is to understand factors that satisfied Muslim Travellers when they travel on group to West Europe as one the most favorite tour product for Indonesians. Data are collected from following areas:

Interview with Muslim Specialist Travel agent, total 10 persons which are Owner and Managers of the travel agents.

Focus roup Discussion (FGD) with 5 Tour leaders of Muslim Travel Specialist. Interview with Chairman of Indonesia Islamic Tourism Communication Forum (IITCF) which have 287 members of Muslim Travel Specialist. Secondary data on this paper including books, journals, internet articles and reports regarding Muslim Travellers, Halal Industry and special need for Muslim based on 
Islamic law and practices. The study was conducted on the first week of November 2016 in Jakarta.

Population is the entire pool from which a statistical sample is drawn. The information obtained from the sample allows statisticians to develop hypotheses about the larger population. Researchers gather information from a sample because of the difficulty of studying the entire population. While sample is the representation of the population. In this paper the population is the Muslim Specialist Travel Agent under Indonesian Islamic Tourism Communication Forum (IITCF) with total members of 287 Travel Agents. Due to time limitation the research only involved interview to 10 of its members in addition to the Chairman of IITCF $\mathrm{H}$. Priyadi Abadi M.Par.

The Focus Group Discussion (FGD) involved 5 Tour Leaders of that Muslim Travel Specialist under IITCF. The 5 tour leaders also represent Muslim Travel Specialist for West Europe tour product. The research location is conducted in Jakarta, Indonesia. The subject of the research is Muslim Travel Specialist under IITCF and is conducted between the periods of 01 November to 10 November

2016 at IITCF office in Jakarta. The research also limited to Muslim Travellers on Group tour purchasing West Europe tour product.

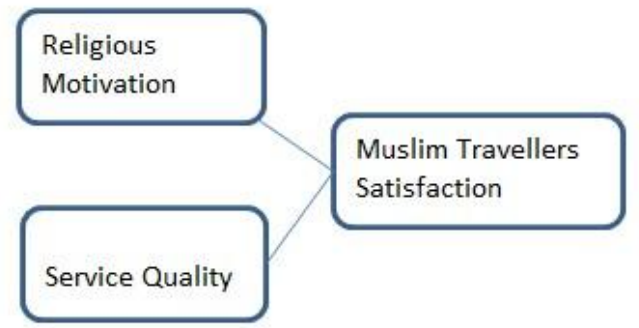

Fig. 1. Hypothesis \& Research Model

H1: There is a positive relationship between religious motivation and Muslim Travellers Satisfaction

$\mathrm{H} 2$ : There is a positive relationship between Service Quality and Muslim Travellers Satisfaction

\section{RESULT}

From the interview with the 10 Muslim Travel Specialist member of Indonesian Islamic Tourism Communication Forum (IITCF) we can conclude following result:

There are 8 members of the group confirming positive relationship betweenreligious motivation and Muslim Travelers satisfaction. These groups believed that Muslim travels to see the Almighty God creation, this could be the nature or the people, and to be grateful to what God gave them. Therefore Muslim Travellers tend to always satisfied when they travel and they accept and embrace what they had from Almighty God.
The other two members are on doubt whether religious motivation is related to satisfaction. The two members found some travellers in the Muslim Group Tour had limited knowledge of Islam and does not really practice Islam. They are joining the tours because their parents or spouse are practicing Islam way of life. Therefore their religious motivation is limited. Based on the result above, it is concluded that $\mathrm{Ha}$ is rejected and $\mathrm{H} 1$ is accepted where there is a positive relationship between religious motivation and Muslim Travellers satisfaction.

On the $\mathrm{H} 2$ we found that 10 out 10 members of the group are fully agree whereby there is positive relationship between Service Quality and Muslim Travellers satisfaction. The interview use SERVQUAL method as the concept and Key Faith Based Need of Muslim Travellers based on CresentRating as the indicators. It is therefore $\mathrm{Ha}$ is rejected and $\mathrm{H} 2$ is accepted.

The research also conducting a Focus Group Discussion (FGD) to understand what efforts made by Travel Agent, especially the Muslim Travel Specialist to satisfied their clients. The FGD involved 5

Tour Leaders, members of IITCF and those who are familiar with West Europe tour product. From the FGD conducted, we can conclude following outcome:

The most important element determined satisfaction is halal food. This is non-negotiable item for any Muslim. Travellers. Therefore efforts should be made by Travel Agent to ensure halal meals across the journey from the Airline meals, hotel meals, restaurants, cafes and any meals including in the tour itinerary should be halal certified. Some clients may ask for the certificate as proof.

Second most important thing is the availability of pray facilities during the tour program, it is common for Muslim Travellers to combine pray time during traveling. The Afternoon pray (Dzuhur) and the Sunset pray (Ashar) can be combined for example as according to Islamic law. Travel agent must ensure that pray facilities is available during this particular time in the tour itinerary.

The next important element is the pray time of each location. The West Europe tour includes different cities from Paris to Amsterdam and Brussels for example, have different pray time. Travel agent must ensure that pray times of each location are provided to their clients. Including in this item is the pray direction (Kiblah) which is different each locations.

One problem noted by the Tour leaders is the difficulties of getting a proper washroom facility in Europe for cleansing before pray. Islamic Law allows the substitution of water bashing cleansing with dusk cleansing (Tayamum). Tour leaders must ensure they understand the proper Tayamum technics and explain them comprehensively to the clients.

Male Muslims obliged to practice Friday Pray every Friday afternoon. This is a must in the tour itinerary when it falls to Friday. Muslim Travel Specialist often organize Friday Pray at the city biggest Mosque, for example at Grande Mosquee in Paris, Islamic Centre Mosque in Brussels, Al-Faith 
Mosque in Amsterdam and Jami Ditib Mosque in Cologne. These are the largest Mosque in these cities and also quite iconic.Tour leaders agreed that conducting Subuh or Fajr Pray at dawn in Jama"ah (congregation) would be a great plus for Indonesian Muslim Travellers. It is now scheduled each day in the program. It is introduced by Travel agent recently and the reception is great from the clients. It is also suggested that a 7 minutes short Islamic lecture to be conducted after the pray. This is a program that Indonesian Muslim Travellers appreciates.

Other indicators provided by CresentRating such as Ramadan Services, No-Non Halal Activities and Separate facilities between male and female, are not substantial by Indonesian Muslim Travellers. On Ramadan Services, Indonesian Muslims do not usually travels. The No-Non Halal activities is consider nice to have, although it is clear that no itinerary or program are made to visit casino or gaming, Indonesian Muslim does not mind watching cabaret shows or belly dance show, which may not Halal. Separate facilities are not important to Indonesian Muslim Travelers. Indonesia is always consider as Liberal Muslims and even in Indonesia we see very limited amount of facilities segregated for female and male except in the Mosque.

This research is on progress and researcher is trying its best to gather more information on Muslim Travellers especially the Indonesians traveling abroad. This is a new phenomenon therefore information and data is limited. Most of the information are gathered by researcher from The Indonesian Islamic Tourism Communication Forum (IITCF). The organization itself is only at infancy stage, established only in 2015. It is informed that more members are coming in the near future. Presently there are 287 active members. This paper is purposely made for Trisakti Tourism Institute on their TGD International Conference held on 14-15 November in Jakarta Convention Centre. This paper is research on progress.

\section{CONCLUSION}

Muslim Travellers is a new phenomenon in Indonesia and on global basis. Muslim Travel Specialist is suggested to set a standard of service for Muslim Travellers. The service standards to keep in mind the Islamic Law and practice. Presently the growing number of Indonesian Muslim Traveling on group tours are mainly to West Europe for non- Islamic countries. Although Europe is a non-Islamic country, Islam as faith is not a new thing and many of Europeans Zeithaml, Valarie A, A.Parasuraman \& Berry, Leonard L, 1990, Delivering Quality Service: Balancing Customer Perceptions and Expectations, the Free Press: A Division of Macmillan, New York

are Islam or familiar with Muslim requirement. This can be different in other places such as North and South America and Australia. Muslim Travel Specialist is suggested to conduct comprehensive research in other places than Europe to make a better tour package for Muslims
Khan, A. H., Haque, Ahasanul \& Rahman, Sabbir M. (2013), What Makes Tourist Satisfied, An Empirical Study on Malaysian Islamic Tourist Destination.

MasterCard-Cresent Rating, Global Muslim Travel Index. (2016).

Priyadi, \& Abadi. (2016). Muslim TravellerSolutions. Jakarta, AMP Press.

Zeithaml, Valarie A, Bitner, Mary Jo \& Gremler, Dwayne D. (2006). Services Marketing: Integrating Customer Focus Across the Firm, $4^{\text {th }}$ Edition, Mc Graw Hill International Edition.

\section{REFERENCE}

